Available online at GSC Online Press Directory

GSC Biological and Pharmaceutical Sciences

e-ISSN: 2581-3250, CODEN (USA): GBPSC2

Journal homepage: https://www.gsconlinepress.com/journals/gscbps

(RESEARCH ARTICLE)

\title{
Parametric optimizations for pectinase production by Aspergillus awamori
}

\author{
Praveen Kumar Dasari * \\ Mother Teresa Pharmacy College, Sathupally, Telangana-507303, India.
}

Publication history: Received on 30 July 2020; revised on 10 August 2020; accepted on 11 August 2020

Article DOI: https://doi.org/10.30574/gscbps.2020.12.2.0247

\begin{abstract}
The present research work is about the production and process optimization of pectinase enzyme using substrate Ficus religiosa leaves by Aspergillus awamori in solid state fermentation. Pectinase having various applications in food industry such as fruit juice extraction, coffee and tea fermentation, textile, paper and pulp industries and in waste-water treatment. Solid-state fermentation is described as a process that take place on a non-soluble material that performs both as support and a source of nutrients, with a reduced among of water, under the action of fermenting agent. Parametric evaluations like time, temperature, size of inoculum, $\mathrm{pH}$ and moisture content were optimized to induce the high yield of pectinase. The increased level of pectinase enzyme production was detected at time $72 \mathrm{hrs}$, temperature $30{ }^{\circ} \mathrm{C}$, optimum inoculum level was $50 \% \mathrm{v} / \mathrm{w}, \mathrm{pH} 5$ and $60 \% \mathrm{v} / \mathrm{w}$ moisture content of the substrate were best for the maximum production of pectinase in solid-state condition. A remarkable enzyme production was enhanced and recorded when the basal medium was supplemented with carbon ( $4 \%$ glucose) and nitrogen (ammonium sulphate, $0.4 \%)$ sources.
\end{abstract}

Keywords: Ficus religiosa leaves; Aspergillus awamori; Pectin; Solid-state fermentation

\section{Introduction}

Pectins are high molecular weight acid polysaccharides, predominantly made up of $\alpha-(1 \rightarrow 4)$ linked D-galacturonicacid remainder with a small number of rhamnose remains in the main chain and arabinose, galactose and xylose on its side chain [1-4]. Pectinases are enzymes that break down pectin which is polysaccharide that available in plant cell walls. Pectinases are pectic enzymes; they are classified into pectinesterase, polygalacturonase and protopectinase. The mechanism employed to cleave a peptide bond that involves making an aminoacid residue that has cysteine and threonine or a water molecule nucleophilic to such an extent that it can attack the peptide carboxyl group. Pectinase enzymes are mostly applied in the process of degradation of plant materials, including speeding up the extraction of fruit juice from fruit, like apples and sapota etc. Pectinases are also having various industrial applications [5], food industry, biotechnological industry, coffee and tea fermentation, oil extraction, enhancement of chromaticity and stability of red wines, textile, paper and pulp industries and in waste-water treatment. Solid-state fermentation [SSF] is a process that take place on a non-soluble material that performs both as support and a source of nutrients, with a reduced among of water, under the action of fermenting agent [6]. Pectinase production has been reported from bacteria including actinomycetes [7-9], yeast $[10,11]$ and fungi $[12,13]$.

Keep in view of the importance pectinase enzyme and the advantage of SSF, the present investigation proposed to study the production and parametric optimization of pectinase enzyme from cheaply and abundantly available raw material.

\footnotetext{
${ }^{*}$ Corresponding author: Praveen Kumar Dasari
} 


\section{Material and methods}

\subsection{Substrate}

Ficus religiosa leaves was collected from college garden, sathupally and dried naturally under sunlight, powdered, packed in a closed container and stored until further use.

\subsection{Microorganism}

Aspergillus awamori was used for the production of pectinase enzyme using Ficus religiosa leaves as substrate. Potato dextrose agar medium was prepared for the maintenance and sub culturing of the microorganism.

\subsection{Preparation of inoculum}

Streaking is done on pure potato dextrose agar slants from the old culture of Aspergillus awamori and streaked agar slants are incubated at $30^{\circ} \mathrm{C}$ for 3 days.

\subsection{Development of inoculum}

$10 \mathrm{ml}$ of sterile distilled water were added to 3 days old streaked agar slant, from that $1 \mathrm{ml}$ of suspension (approximately $10^{5}-10^{6}$ spores $/ \mathrm{ml}$ ) was used as the inoculum to each conical flask contain culture medium.

\subsection{Fermentation}

SSF was performed in 250-mL conical flask by measuring $100 \mathrm{~mL}$ of medium contain (in $\mathrm{g} / \mathrm{L}$ ): $\left(\mathrm{NH}_{4}\right)_{2} \mathrm{SO}_{4} 0.1$, $\mathrm{MgSO}_{4} \cdot 7 \mathrm{H}_{2} \mathrm{O} 0.5, \mathrm{KH}_{2} \mathrm{PO}_{4} 0.5$ and $\mathrm{FeSO}_{4} \cdot 7 \mathrm{H}_{2} \mathrm{O}$ 0.005. To carry out the experiment, the initial moisture content of the substrate was adjusted to $50 \% \mathrm{v} / \mathrm{w}$. The pH adjusted to 5.0 and inoculum level of the medium was $1 \mathrm{ml}$. The flasks were incubated at $30^{\circ} \mathrm{C}$. After every $24 \mathrm{hrs}$ enzyme assay was carried out and values are recorded.

\subsection{Enzyme assay}

Polygalacturonase activity was detected by measuring the liberated reducing groups from substrate using a 3.5 dinitro salicylic acid (DNS) reagent assay. To the reaction mixture $0.8 \mathrm{ml}$ of $1 \%$ pectin, $67 \%$ methoxylated Braspectina in $0.2 \mathrm{M}$ acetate buffer, $0.2 \mathrm{ml}$ of crude enzyme solution were added and incubated at $50{ }^{\circ} \mathrm{C}$ for $10 \mathrm{~min}$. After $10 \mathrm{~min} 1 \mathrm{ml}$ of DNS reagent was placed in test tubes and the test tubes are shaken well to mix all the components and to that mixed solution $8 \mathrm{ml}$ of distilled water was injected to avoid the turbidity. The absorbance was detected at $540 \mathrm{~nm}$ using spectrophotometer. The enzyme and substrate blanks are run similarly. One enzyme unit of endopolygalacturonase (EC 3.2.1.15) is the number of micromoles of reducing sugars quantify in terms of monogalactauronic acid, produced as a result of the action of $1 \mathrm{ml}$ of enzyme extract in one minute at $30{ }^{\circ} \mathrm{C}$ temperature.

\section{Results and discussion}

The production of pectinase is modulated by nutritional, physical and chemical factors. Microbes are the best producers of enzymes that are helpful for peoples need. The present investigation focuses on the influence of various physical and chemical parameters for production enzyme. For this experiments are performed in triplicates and the results noted are the mean values. The nutritional parameters could be effectually keeping track in this process for the maximum enzyme production of end product by keeping physicochemical parameters as constant. To detect the effect of time on enzyme production, the medium incubate at different time intervals, after every 24 hrs enzyme assay was carried out and values are recorded. The maximum pectinase enzyme activity was observed at $72 \mathrm{hrs}$. After $72 \mathrm{hrs}$, it was decreased due to depletion of nutrient materials. Pectinase production at different time intervals is shown in the fig.1. 


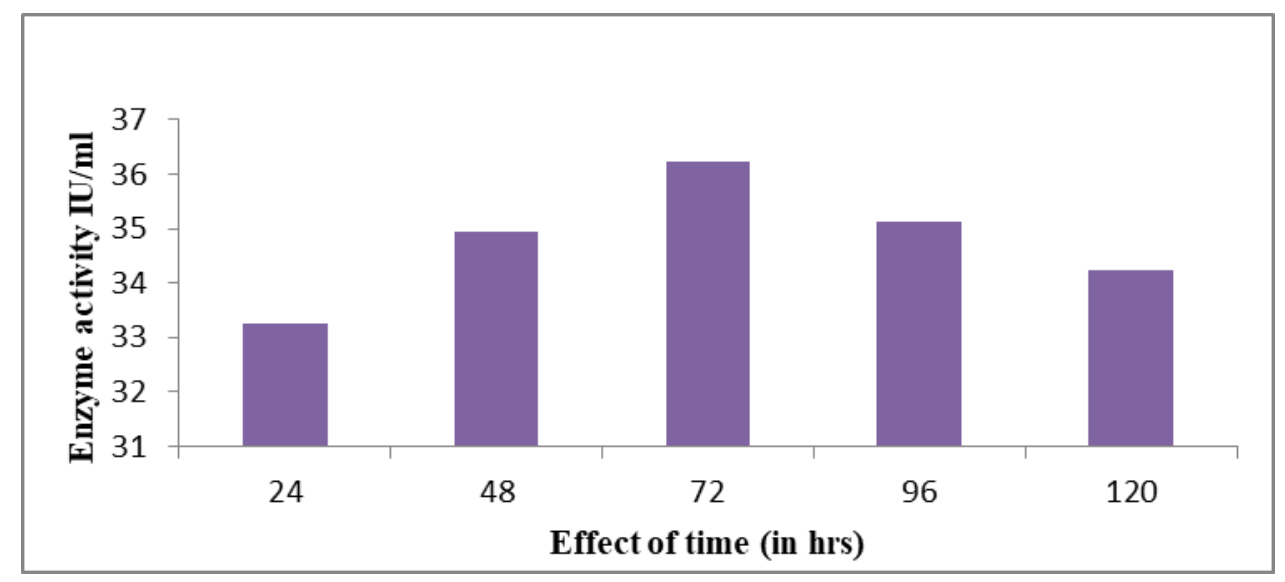

Figure 1 Effect of time on enzyme production

The temperature of the substrate is very crucial in SSF as it ultimately affects the growth of the microorganism, spore formation and germination. The maximum amount of pectinase was observed at $30^{\circ} \mathrm{C}$ temperature fig.2. By increase in temperature, decreased pectinase enzyme activity was observed due to heat inactivation of the enzyme.

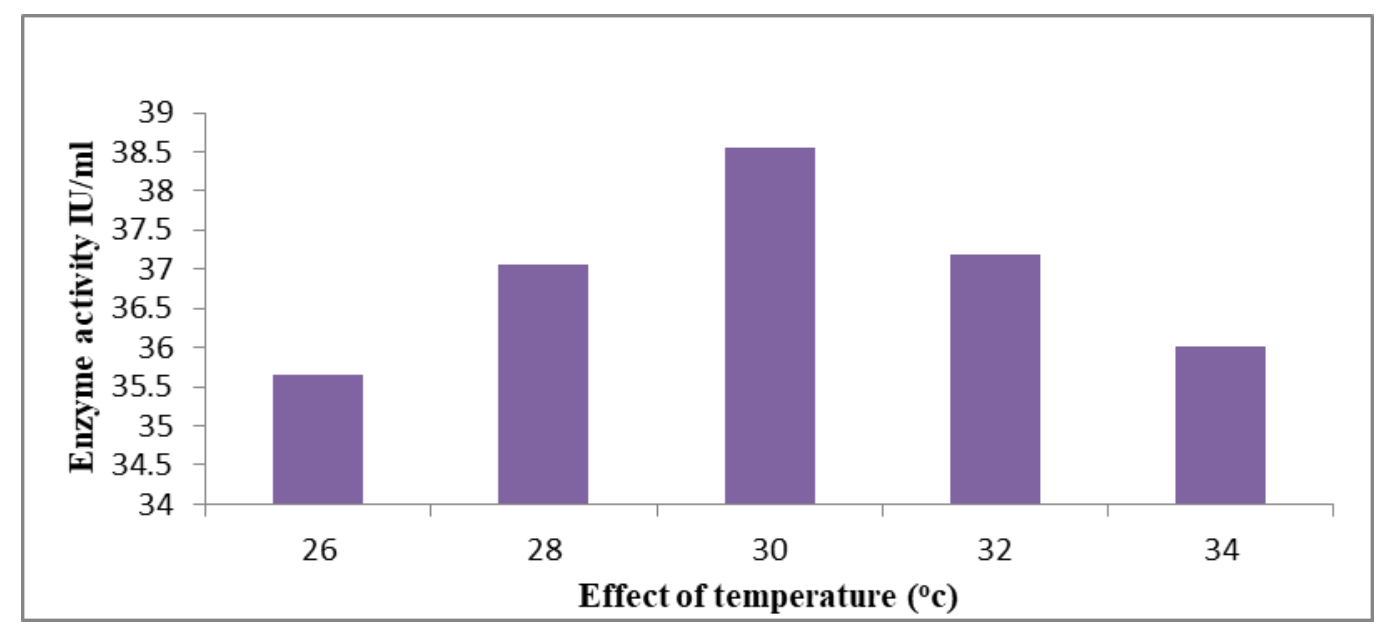

Figure 2 Effect of temperature on enzyme production

To determine the effect of $\mathrm{pH}$, the bacterial nutrient medium was adjusted with different $\mathrm{pH}$ ranges $3,4,5,6$, and 7.0. The maximum production of pectinase was recorded at $\mathrm{pH} 5$ fig.3.

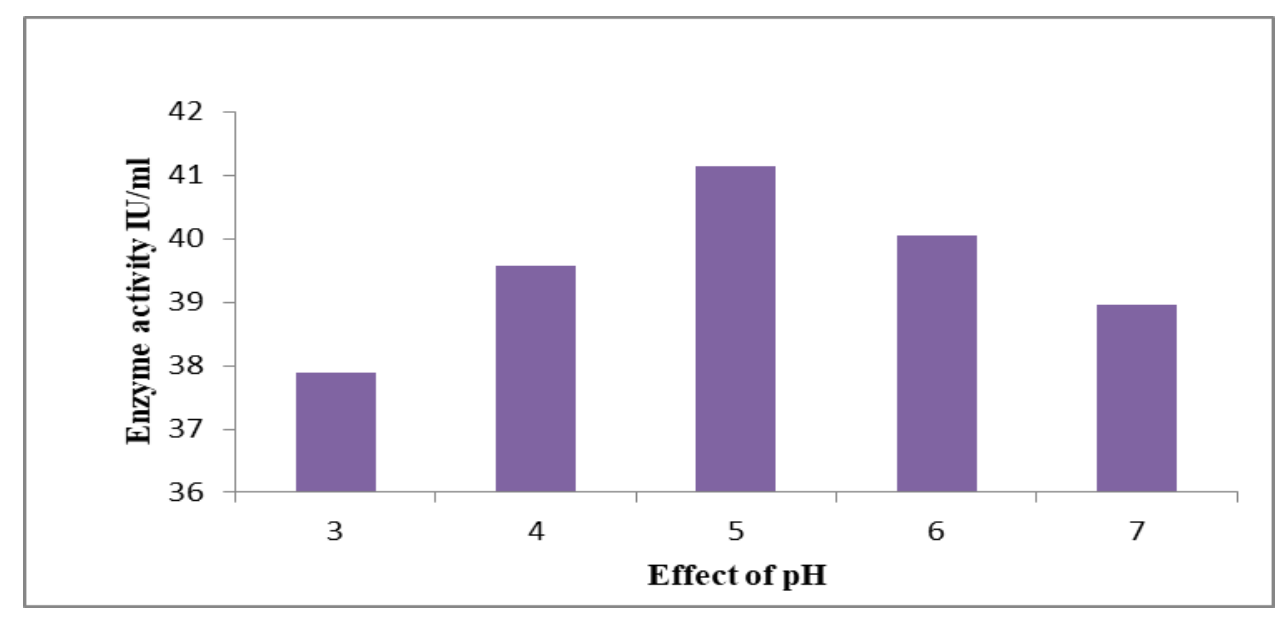

Figure 3 Effect of $\mathrm{pH}$ on enzyme production 
Different inoculum levels were prepared for the production of enzyme $30 \%, 40 \%, 50 \%, 60 \%, 70 \%, 80 \%, 90 \% \mathrm{v} / \mathrm{w}$. The maximum enzyme production was observed at $50 \% \mathrm{v} / \mathrm{w}$ of inoculum fig. 4 .

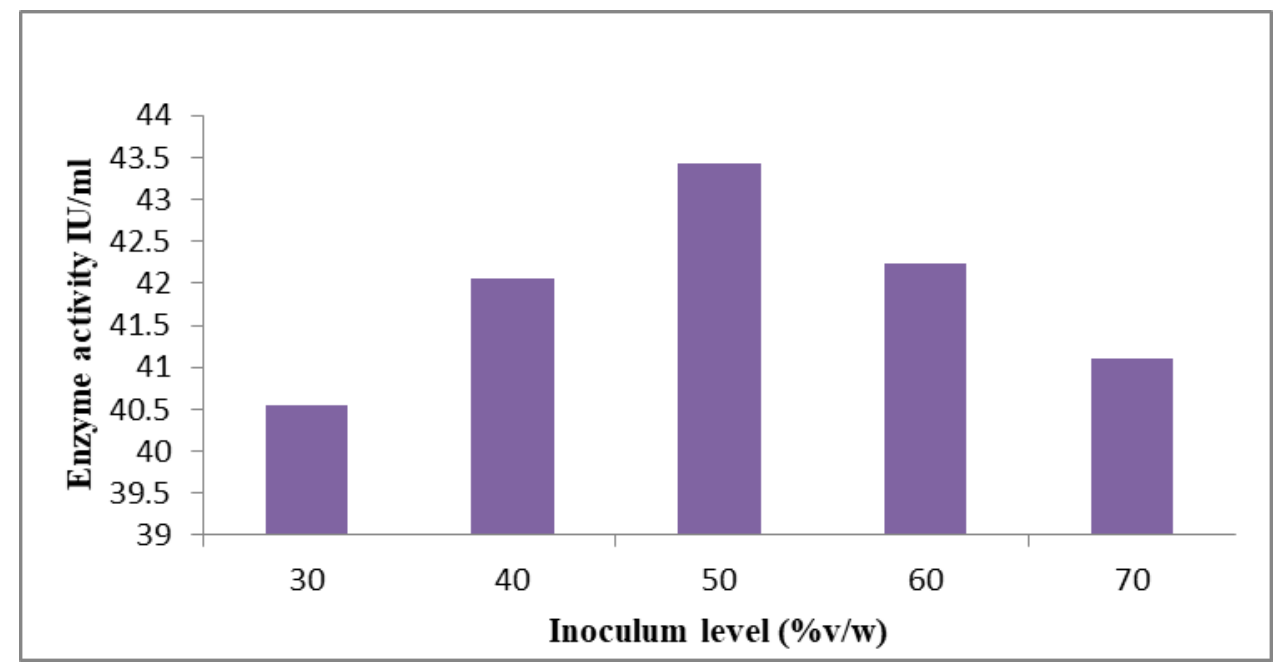

Figure 4 Effect of inoculum level on enzyme production

Moisture content of the substrate is predominant for the production of enzymes in SSF. High moisture content results in decreased substrate porosity, which in turn prevents oxygen penetration, it may cause bacterial contamination. To ascertain the effect of moisture content on enzyme production, different moisture contents $40 \%, 50 \%, 60 \%, 70 \%, 80 \%$, $90 \%$, and $100 \% \mathrm{v} / \mathrm{w}$ were prepared added in each conical flask. The maximum activity was observed at $60 \% \mathrm{v} / \mathrm{w}$ of the moisture content fig.5.

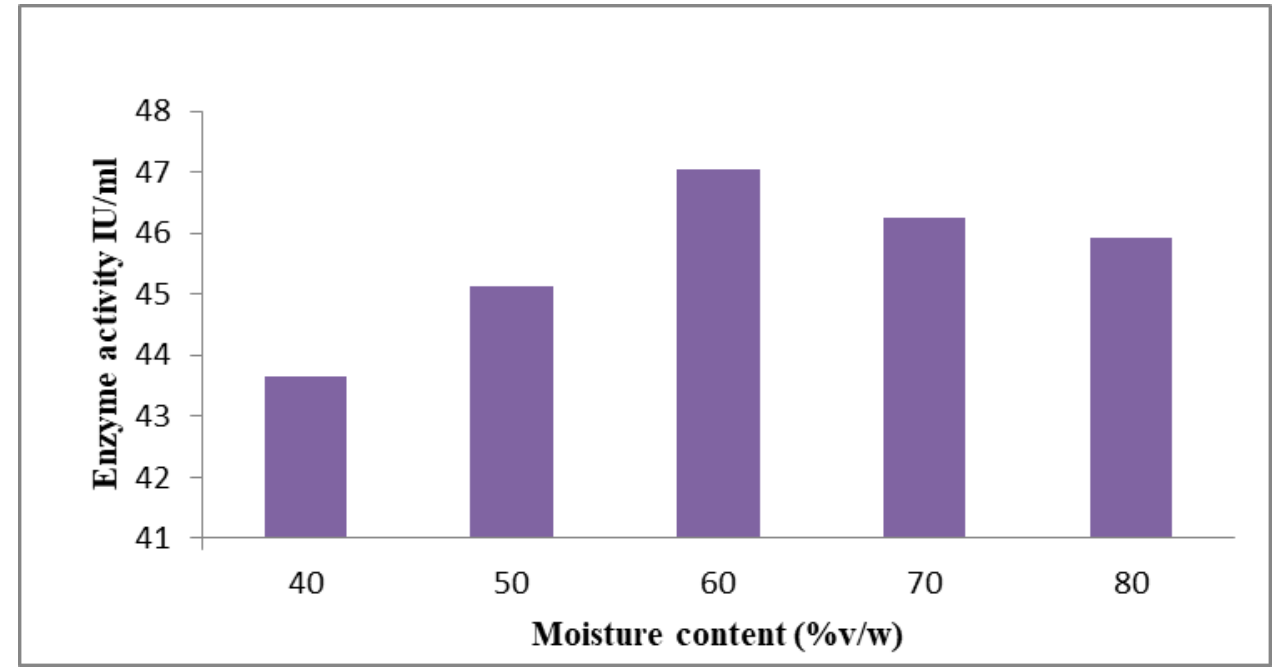

Figure 5 Effect of Moisture content on enzyme production

Five different carbon components were screened for the production of pectinase enzyme which includes sucrose, maltose, glucose, fructose, and lactose. These are enriched with $\% \mathrm{w} / \mathrm{w}$. The results indicate that glucose supplementation gave marginally improved enzyme than other supplementations. Production medium was prepared with different concentrations of glucose like 1,2, 3, 4, 5 and $6 \% \mathrm{w} / \mathrm{w}$. The result shows maximum enzyme production was observed at $4 \% \mathrm{w} / \mathrm{w}$ of glucose concentration fig. 6 . 


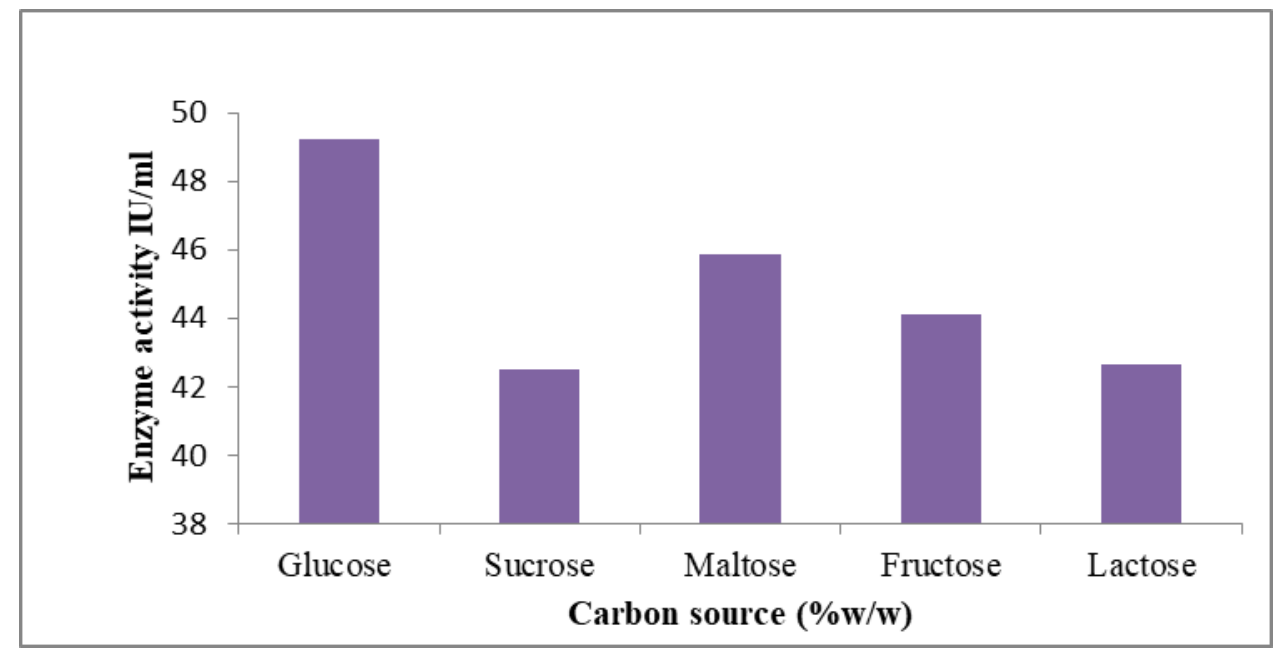

Figure 6 Effect of carbon source on enzyme production

To determine the effect of nitrogen on the enzyme production, the production medium was prepared with different concentrations of ammonium sulphate like $0.1 \%, 0.2 \%, 0.3 \%, 0.4 \%$ and $0.5 \% \mathrm{w} / \mathrm{w}$ were dispersed in $250 \mathrm{ml}$ conical flasks. The result indicates that maximum enzyme production was observed at $0.4 \% \mathrm{w} / \mathrm{w}$ concentration fig.7.

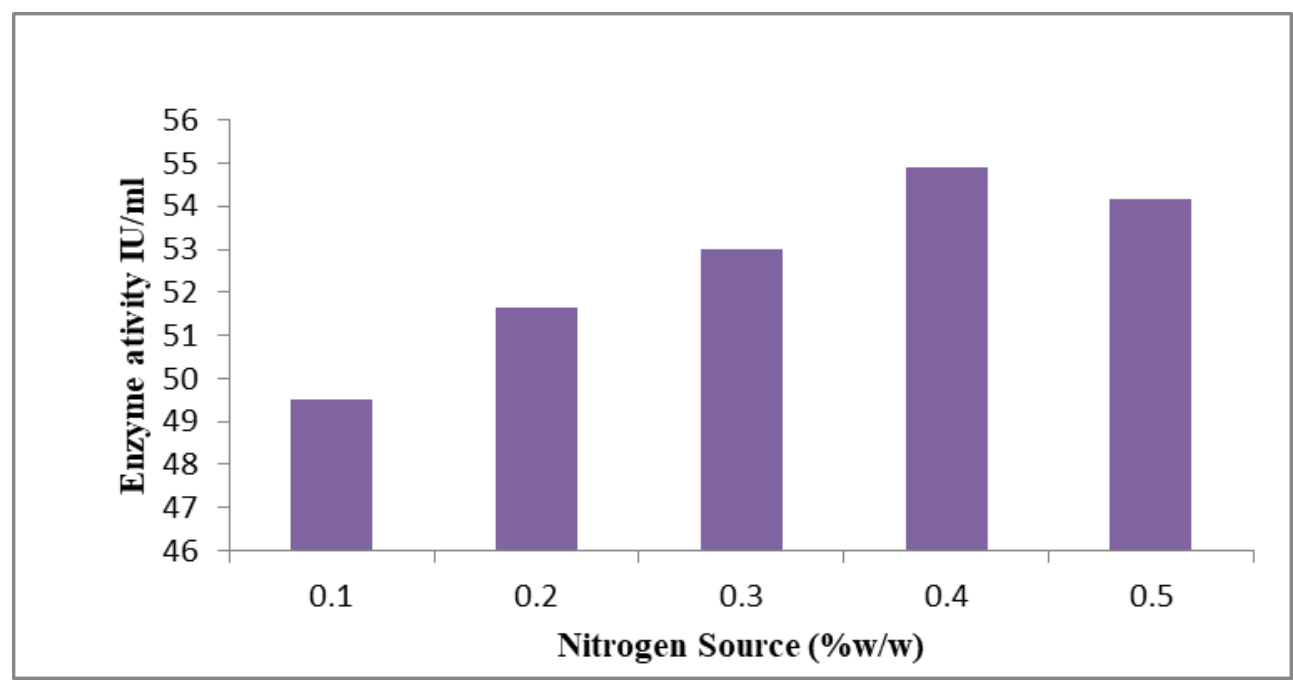

Figure 7 Effect of nitrogen source on enzyme production

\section{Conclusion}

In conclusion, the author reported production and optimization of pectinase enzyme from cheaply and abundantly available raw material. Production of pectinase at optimum time, temperature, $\mathrm{pH}$ and moisture content enhance the enzyme yield. A remarkable enzyme production was enhanced and noticed when the basal medium was supplemented with carbon (glucose) and nitrogen (ammonium sulphate) sources.

\section{Compliance with ethical standards}

\section{Acknowledgments}

The author expresses his sincere thanks to the management, Mother Teresa Pharmacy College, Sathupally, Telangana for providing the necessary facilities to carry out the research work. 


\section{Disclosure of conflict of interest}

The author declare no conflict of interest.

\section{References}

[1] Lang H and Do-Renberg H. (2000). Perspectives in the biological function and the technological application of polygalacturonases. Applied Microbiology and Biotechnology, 53, 366-375.

[2] Deul H and Stutz E. (1958). Pectic substances and pectic enzymes. Advances in Enzymology, 20, 341-382.

[3] Kapoor M, Beg QK, Bhushan B, Dadhich KS and Hoondal GS. (2000). Production and partial purification and characterization of a thermoalkalistable polygalacturonase from Bacillus sp. MG-cp-2. Process Biochemistry, 36, 467-473.

[4] Singh SA, Plattner H and Diekmann H. (1999). Exopolygalacturonate lyase from a Thermophilic Bacillus sp. Enzyme and Microbial Technology, 25, 420-425.

[5] Jayani RS, Saxena S and Gupta R. (2005). Microbial pectinolytic enzymes: a review. Process Biochemostry, 40, 2931-44.

[6] Couto SR and Sanroman MA. (2006). Application of solid-state fermentation to food industry - a review. Journal of Food Engineering, 76, 291-302.

[7] Cao J, Zheng L and Chen S. (1992). Screening of pectinase producer from alkalophilic bacteria and study on its potential application in degumming of ramie. Enzyme Microbial Technology, 14, 1013-1016.

[8] Bruhlmann F, Kim KS, Zimmerman W and Fiechter A. (1994). Pectinolytic enzymes from actinomycetes for the degumming of ramie bast fibers. Applied and Environmental Microbiology, 60, 2107-2112.

[9] Beg QK, Bhushan B, Kapoor M and Hoondal GS. (2000). Effect of amino acids on production of xylanase and pectinase from Streptomyces sp. QG-11- 3. World Journal of Microbiology and Biotechnology, 16, 211-213.

[10] Reid I and Ricard M. (2000). Pectinase in paper making: solving retention problems in mechanical pulps bleached with hydrogen peroxide. Enzyme Microbial Technology, 26, 115-123.

[11] Blanco P, Sieiro C and Villa TG. (1999). Production of pectic enzymes in yeast. FEMS Microbiology Letters, 175, $1-9$.

[12] Huang LK and Mahoney RR. (1999). Purification and characterization of an endo-polygalacturonase from Verticillum albo-atrum. Journal of Applied Microbiology, 86, 145-146.

[13] Gummadi SN and Panda T. (2003). Purification and biochemical properties of microbial pectinases: a review. Process Biochemistry, 38, 987-996.

\section{How to cite this article}

Dasari PK. (2020). Parametric optimizations for pectinase production by Aspergillus awamori. GSC Biological and Pharmaceutical Sciences, 12(2), 93-98. 